Dirāsāt: Jurnal Manajemen dan Pendidikan Islam, Vol. 6, No. 2, Desember 2020: 144-157. ISSN (Online): 2550-1038, ISSN (Print): 2503-3506. Website: journal.unipdu.ac.id/index.php/dirasat/index. Dikelola oleh Program Studi Manajemen Pendidikan Islam (MPI) Program Pascasarjana Universitas Pesantren Tinggi Darul Ulum (Unipdu) Jombang Indonesia.

\title{
Pendidikan Islam dan Upaya Membumikan Kesadaran Pluralisme
}

\section{Nur Khoironi, Abdul Muhid}

UIN Sunan Ampel Surabaya

Email: khoironi1988@gmail.com, abdulmuhid@uinsby.ac.id

Abstrak: Karya ilmiah ini merupakan hasil kajian pustaka tentang upaya membumikan kesadaran pluralisme melalui pendekatan pendidikan Islam. Seperti yang diketahui bahwa pluralisme adalah realitas yang betul-betul terjadi di sekitar kehidupan kita sehari-hari, baik pada agama, budaya, pendidikan, ras dan suku. Adanya keberagaman tidak lain merupakan bagian dari sunnatullāh. Maksudnya, keberagaman merupakan bagian dari kehendak Tuhan sebagai pencipta manusia dan seluruh makhluk di jagad raya ini. Tentunya, dengan tujuan agar perbedaan diambil sisi positifnya sebagai jalan pemandu untuk bekerja sama, introspeksi diri, dan tolong-menolong. Karena jikalau Allah menghendaki sebuah keseragaman maka niscaya Allah menjadikan umat yang tunggal, satu suku, satu bangsa, satu agama, tetapi pada faktanya tidak demikian. Dalam Alquran, Allah secara tegas menyatakan bahwa sengaja menjadikan kita bermacam-macam agar kita saling mengenal satu sama lain. Dalam konteks ke-Indonesiaan, kesadaran tentang kemajemukan ini perlu dan harus terus dijaga demi keutuhan bangsa dan negara, sebagaimana Rasulullah SAW menjaga keutuhan kota Madinah diatas perbedaan agama, suku, ras dan kabilah.

Kata kunci: Pendidikan Islam, pluralisme.

Abstract: This scientific work is the result of a literature review about efforts to popularized pluralism awareness through the approach of Islamic education. As we know, that pluralism is a reality that really occurs in our daily lives, both in religion, culture, education, race and ethnic. The existence of diversity is nothing that become a part of sunnatulläh. That is, diversity is the part of God's will as the creator of human beings and all life in the universe. Of course, with the aim of making the positive side of the difference taken as a guide for cooperation, selfintrospection, and help. Because, if God wants a uniformity then surely Allah will make a single human, one tribe, one nation, one religion, but in fact it is not. In the holy Qur'ān, God explicitly states that deliberately makes us diverse so that we able to know each other. In Indonesian context, awareness of diversity needs to be and must continue to be maintained for the integrity of the nation and state, as the Prophet Muhammad kept the integrity of Medina city above the differences in religion, ethnic, race and tribe.

Keywords: Islamic Education, Pluralism.

\section{Pendahuluan}

Kerusuhan-kerusuhan yang terjadi di berbagia daerah di Indonesia dan dunia, seperti kasus Situbondo, Syiah Sampang, dan kasus Ambon, pada dasarnya dampak dari konflik yang dilatarbelakangi perbedaan dan radikalisme. Klaim atas kebenaran, ditambah lagi dengan persepsi bahwa perbedaan adalah suatu hal yang buruk dan menakutkan sudah begitu rupa mendarah daging dalam jiwa manusia, dan bahkan umat beragama, sehingga masing-masing kelompok mengklaim bahwa dirinyalah yang paling benar, sedangkan kelompok lain salah, yang sering menjadi sebab tersulutnya pertikaian. Akibat dari perseteruan adalah kesengsaraan semua pihak, baik bagi yang bertikai maupun 
tidak. Dan pada akhirnya konflik hanya menyisakan kerugian yang menyeluruh ke berbagai pihak.

Dengan adanya perseteruan ataupun kerusuhan di suatu daerah pada akhirnya merambah ke daerah lain, baik yang berada dalam satu wilayah maupun di wilayah yang berbeda. Memanasnya kondisi di suatu daerah, seperti adanya konflik antar agama memicu daerah lain untuk melakukan hal yang serupa, hal tersebut dikarenakan adanya ikatan emosional yang kuat. Kejadian serupa pernah terjadi di daerah Mataram, Lombok beberapa tahun silam saat umat Islam melakukan tablīgh akbar sebagai bentuk respons terhadap kondisi umat Islam di Ambon yang berakhir dengan kerusuhan, berupa perusakan terhadap tempat-tempat ibadah dan sarana pendidikan umat Kristiani. Terlepas dari provokator dan lain sebagainya yang bisa menjadi kambing hitam dalam setiap chaos, yang jelas umat beragama belum mempunyai kontrol emosi yang memadai sehingga begitu mudah terpancing untuk melakukan berbagai macam tindakan anarki. Sentimen keagamaan dan fanatisme buta paling tidak banyak memberi andil atas terciptanya setiap adegan kerusuhan dan terjadinya konflik. Konflik atas nama agama pada umunya disebabkan oleh penyimpangan arah proses sosial yang berkolerasi logis dengan bentuk-bentuk penyimpangan interaksi sosial antar umat beragama.

Hal yang sangat mengejutkan diungkap dari hasil survei Lembaga Kajian Islam dan Perdamaian (LaKIP) Paramadina yang dilakukan pada Oktober 2010 hingga Januari 2011, dengan responden 590 dari total 2.639 guru PAI dan 993 siswa beragama Islam dari jumlah 611.678 murid sekolah menengah di Jabodetabek. Menyangkut toleransi, misalnya, 62,7\% responden guru PAI keberatan non-muslim membangun tempat ibadah dilingkungan tempat tinggal mereka, sedangkan siswa yang keberatan 40,7\%. Saat ditanya jika non-muslim menjadi kepala sekolah, 57,2\% guru dan 45,2\% siswa tidak setuju. Hasil survei juga menunjukkan tingkat dukungan terhadap aksi kekerasan cukup tinggi. Begitu juga tingkat kesediaan mereka terlibat dalam aksi kekerasan terkait isu agama. ${ }^{1}$ Dari fenomena tersebut setidaknya dapat dijadikan kesimpulan awal bahwa sampai saat ini, kesadaran pluralitas dalam beragama belum menyentuh sisi kesadaran paling dalam pada diri para pemeluk agama. Artinya, sloganslogan bahwa agama mengajarkan cinta kasih dan perdamaian, tidak manyukai tindakan kejahatan dalam bentuk apapun hanyalah omong kosong.

Di sinilah paling tidak, perlu diperhatikan kembali tentang peran Pendidikan Islam bagi umat Islam itu sendiri. Islam sebagai agama rahmah lial- 'àlamīn (rahmat bagi alam semesta) sudahkah dapat diwujudkan? Pasalnya, posisi umat Islam sebagai mayoritas disatu sisi sangatlah tidak menguntungkan. Ironisnya ternyata umat Islam dapat dikatakan hampir banyak ikut serta dalam setiap aksi kerusuhan. Mengapa bisa terjadi demikian? tentunya ada yang salah, "there is something wrong" atau bisa jadi pendidikan Islam belum mampu mendidik umatnya menjadi kaum pluralis? Meskipun sudah banyak ayat

\footnotetext{
${ }^{1}$ Afif Syaiful Mahmudin, "Pendidikan Islam dan Kesadaran Pluralisme," Ta'limuna: Jurnal Pendidikan Islam 7, no. 1 (Maret 2018).
} 
Alquran dan hadis mengenai toleransi beragama. Ini perlu dikaji kembali sebagai upaya perbaikan mutu Pendidikan Islam itu sendiri.

Kebanggaan sebagai umat yang terbaik, khayr ummah, hendaknya tidak melenakan umat Islam dari berbuat kebajikan yang nyata. Lagi pula kebanggaan semacam itu hanyalah akan menjadi beban berat yang mesti dipikul dan akan menjadi bahan tertawaan bila tidak dapat direalisasikan dalam setiap aktifitas hidupnya sehari-hari sesuai dengan predikat yang disandang. Dalam buku Membumikan Alquran karya M Quraish Shihab disebutkan,

"Agama Islam, agama yang kita anut dan dianut oleh ratusan juta kaum muslim seluruh dunia, merupakan way of life yang menjamin kebahagiaan hidup pemeluknya di dunia dan akhirat kelak. Ia mempunyai satu sendi utama yang esensial; berfungsi memberi petunjuk ke jalan yang sebaikbaiknya." Petunjuk kejalan yang baik (șirāt al-mustaqìm) itu terangkum dalam Alquran sebagai kitab pedoman umat Islam. Umat Islam dituntut untuk mempelajari ajarannya untuk kemudian diamalkan dalam kehidupan sehari-hari."2

Menanggapi "pandangan" miring tentang Islam sebagai agama kaum teroris, yang gemar berbuat onar dan kerusuhan, hendaklah merujuk kembali kepada Alquran dan hadist untuk mendapatkan keterangan yang lebih otentik. Tentang konsep penghargaan terhadap agama lain misalnya, atau konsep berjihad memerangi penganut agama lain, haruslah benar-benar didudukkan sesuai porsinya masing-masing. Ini sangat penting, bukan hanya bagi orang lain di luar Islam, namun bagi orang Islam sendiri agar pemahaman terhadap "ruh" Alquran dan hadist benar sebagaimana tuntunan Rasulullah SAW.

\section{Hakikat Pendidikan Islam}

Dalam upaya mewujudkan Islam yang raḥmah li-al-'âlamīn, maka umat Islam dituntut dan dituntun untuk bisa cerdas dalam beragama. Keharusan cerdas dalam beragama ini membuat peran pendidikan Islam menjadi sangat urgen. Sebab bagaimana seseorang bisa menjelma menjadi cerdas jika perilakunya masih jauh dari apa yang disebut pendidikan. Akan tetapi ketika kita berbicara mengenai pendidikan, khususnya Pendidikan Islam dalam konteks keIndonesiaan, maka akan kita dapati sebuah fakta yang sangat memilukan sekaligus memalukan. Bagaimana tidak, sebuah bangsa besar yang dihuni oleh mayoritas muslim dalam realita masih saja berada dalam buritan khususnya disektor pendidikan. Konsep Undang-undang dasar negara kita tentang mencerdaskan kehidupan bangsa seakan tak lebih dari bualan kosong di warung kopi belaka. Ini tidak lain karna belum adanya strategi yang pas dan mantap dalam upaya membangun kualitas pendidikan pada bangsa yang sudah berumur lebih dari setengah abad ini, atau mungkin penduduk bangsa ini belum

\footnotetext{
${ }^{2}$ M. Quraish Shihab, Membumikan Al-Qur'an (Bandung: Mizan, 1995), 33.
} 
mengerti benar akan hakikat dari pendidikan khusunya pendidikan Islam dalam menyikapi segala perbedaan.

Dalam laporan UNDP (United Nations Development Programme) tahun 2004, HDI (Human Development Index) Indonesia kini berada diperingkat 111 dari 175 Negara. $^{3}$ Ini tentunya merupakan sebuah cambukan yang teramat pedih bagi bangsa besar yang dihuni mayoritas muslim yang agamanya mengajarkan akan pentingnya pendidikan. Karenanya, kita perlu pahami kembali apa hakikat dari pendidikan Islam sebenarnya, kemudian mengevaluasi sejauh mana pendidikan Islam memberikan bekas bagi peserta didiknya dalam menghadapi tantangan zaman dari masa ke masa. Dengan demikian kita bisa tahu apakah kita perlu melakukan reaktualisasi dan reposisi pendidikan Islam dan kemudian menggagas strategi yang dianggap pas, mantap dan efektif dalam internalisasi nilai-nilai pendidikan Islam bagi peserta didik menghadapi tantangan zaman.

Telah cukup banyak definisi yang dikemukakan para pakar pendidikan Islam mengenai hakikat dari pendidikan Islam tersebut, di antaranya rumusan hasil seminar pendidikan Islam se Indonesia 7-11 Mei 1960 di Cipayung Bogor menjelaskan hakikat pendidikan Islam adalah bimbingan yang dilakukan oleh orang dewasa kepada terdidik dalam masa pertumbuhan agar ia memiliki keperibaian muslim. ${ }^{4}$ Muhaimin menjelaskan bahwa hakikat pendidikan Islam merupakan aktifitas pendidikan yang diselenggarakan atau didirikan atas hasrat dan niat untuk mengejawantahkan ajaran dan nilai-nilai Islam. ${ }^{5}$

Dari dua penjelasan tentang hakikat pendidikan di atas, kita dapat melihat bahwa muara akhir dari pendidikan Islam adalah membentuk keperibadian muslim dengan mengejawantahkan nilai-nilai ajaran Islam dalam kehidupan. Berbeda dengan dua definisi ini yang lebih cendrung memasung pengertian hakikat pendidikan Islam sebagai bimbingan atau pendidikan, Syafi'i Ma'arif lebih luas mengartikan hakikat pendidikan Islam adalah segala upaya untuk menggali dan mengembangkan potensi anak didik untuk diarahkan kepada citacita universal Islam tentang manusia berupa terciptanya pribadi muslim yang cerdas secara intelektual, anggun secara moral, dan terampil dalam amal bagi kepentingan sesama.

Seseorang yang berkeperibadian muslim pastilah menjadikan Islam sebagai acuan berpribadi. Dengan Islam sebagai acuan kepribadian, yang tentunya diadopsi dari kecerdasan memahami agama maka seorang muslim dengan sendirinya akan terlahir sebagai dermawan dan rahmat yang senantiasa memberikan rahmatnya kepada siapa dan apa saja dijagat raya ini. Pada kondisi seperti ini, maka Islam tidak akan lagi dipandang sebagai mesin penghancur peradaban karena seringnya berbuat kekerasan dan terorisme atas nama agama, akan tetapi Islam akan menjelma laksana oksigen yang selalu dibutuhkan oleh siapapun di manapun dan kapanpun di muka bumi ini.

\footnotetext{
${ }^{3}$ Ahmad Syafi'i Ma'arif, Islam Dalam Bingkai (Yogyakarta: Pustaka SM 2009), 214.

${ }^{4}$ Nur Uhbiyati, Pendidikan Islam (Jakarta: Pustaka Setia, 2000), 19.

${ }^{5}$ Muhaimin, Rekonstruksi Pendidikan Islam (Jakarta: Pustaka setia, 2009), 23.
} 
Tentunya kita sangat berharap agar peradaban yang akan datang tidak berubah menjadi kebiadaban yang liar dan brutal. Untuk itu maka pendidikan Islam haruslah bisa menjadi solusi dalam mengantisipasi kebiadaban peradaban dimasa mendatang serta memberikan tawaran alternatif yang baik bagi corak dan warna yang akan dikuaskan dimasa mendatang. Karena pentingnya peranan pendidikan Islam tersebut, maka ia harus memiliki acuan dan pijakan yang jelas. Sehingga pendidikan Islam tidak seperti layangan putus yang tak tahu kemana arah angin akan membawanya. Pendidikan Islam yang hendak kita kembangkan haruslah kita bangun diatas paradigma yang kokoh secara spritual, unggul secara intelektual dan anggun secara moral dengan Alquran (bayān ilāhī) sebagai pijakan utama dan pertamanya. ${ }^{6}$

\section{Penanaman Pluralisme Agama dalam Pendidikan Islam}

Pluralisme agama di negeri ini merupakan realitas empiris yang tidak bisa dipungkiri dan dibantah. Membantahnya sama saja dengan membantah semboyan Bhineka Tunggal Ika yang selama ini kita sepakati sebagai semboyan dari bangsa kita. Pluralisme menurut Syafi'i Ma'arif merupakan sebuah tolok ukur bagi kemajuan bangsa Indonesia. Dengan demikian kita tidak akan bisa sampai pada titik kemajuan, jika prinsip pluralisme belum melekat dalam mindset kita sebagai penduduk di sebuah negara dengan corak dan warna yang beragam. Pluralisme bukanlah barang baru dalam bingkai keIndonesiaan, jauh sebelum negara ini dibentuk, pluralisme telah tumbuh dan berkembang sebagai buah dari masyarakat yang beragam. Dengan menyadari kenyataan inilah kemudian para founding fathers menetapkan negara ini bukan menjadi negara agama atau negara sekuler. Pilihannya berada tepat diantara keduanya. Pilihan untuk menjadi negara non agama waktu itu memang memberikan dasar-dasar yang kuat bagi bangsa ini untuk bersikap toleran, menghargai kemajemukan dan menjunjung tinggi perbedaan. Sedangkan pilihan untuk tidak menjadi negara sekuler, jelas membuktikan bahwa negara ini rakyatnya bisa dibilang religious society, masyarakat yang ber-Tuhan, bukan anti tuhan.

Seiring dengan berjalannya waktu, kecermatan dan kecerdasan founding fathers yang telah merumuskan dengan apik apa yang menjadi kebutuhan bersama, mulai habis dan terkikis. Perputaran waktu dengan segala efek zaman yang dilaluinya telah menjadikan agama sebagai ideologi massa, bukan sebagai agen transformasi masyarakat. Dengan situasi seperti itu, agama yang diharapakan memiliki posisi strategis dalam merespon masalah-masalah sosial kemanusiaan yang terjadi di masyarakat akhirnya mandul. Kondisi seperti ini tentunya tak lepas dari tanggung jawab pendidikan, karena pendidikan sebagai proses pemberdayaan dan pembudayaan individu dan masyarakat, dan ini merupakan salah satu media yang sangat efektif untuk mewujudkan masyarakat

\footnotetext{
${ }^{6}$ Ahmad Syafii Ma'arif, Masa Depan Bangsa dalam Taruhan (Yogyakarta: Pustaka SM, 2000), 78.
} 
yang dinamis di tengah pluralitas agama. Sebaliknya ketika pendidikan salah dalam melangkah maka agama justru berubah menjadi bom yang siap mempropagandakan dan menghancurkan kehidupan. Melalui pendidikan, manusia diperkenalkan tentang eksistensi diri, hubungan dengan sesama, alam dan Tuhannya. Sehingga idealnya, pendidikan agama Islam yang berlangsung selama ini, seharusnya dapat mengantisipasi dan mencari solusi terhadap terjadinya pertikaian, perselisihan, pembunuhan, dan lainnya, yang antara lain berakar dari persoalan agama.

Namun demikian, kenyataan yang muncul selama ini menunjukkan bahwa benih-benih konflik, bahkan konflik yang muncul apabila ditelusuri lebih lanjut cenderung disebabkan karena persoalan agama dan menjadikan agama sebagai alat dan "slogan" yang ampuh untuk menyulut kerusuhan. Hal ini satu sisi merupakan indikasi "belum berhasilnya" pendidikan agama Islam terutama di sekolah dalam menanamkan nilai-nilai agama sebagai rahmah li-al-'älamīn pada anak didik, yang salah satunya disebabkan operasionalisasi dari pendidikan yang hanya cenderung mengarah pada bagaimana menanamkan doktrin-doktrin agama dengan hanya menggunakan metode pendekatan teologis-normatif.

Memahami agama dengan hanya menggunakan pendekatan ini akan melahirkan sikap keberagamaan yang eksklusif, truth claim, tidak ada dialog parsial, saling menyalahkan, saling mengkafirkan, yang membentuk pengkotak-kotakkan umat, tidak ada kerjasama dan tidak terlihat adanya kepedulian sosial. ${ }^{7}$ Sehingga yang sering ditonjolkan hanya perbedaannya, walaupun pada dasarnya masing-masing agama mempunyai perbedaan, karakter, dan ciri khas yang berbeda-beda. Sebaliknya, nilai toleransi, kebersamaan, tenggang rasa, selama ini kurang ditonjolkan. Perbedaan yang ada dari keragaman agama harus bisa kita lukiskan dengan baik dalam bingkai ke-Indonesiaan sehingga bisa menghasilkan sebuah lukisan yang indah. Tentunya dengan formula "bersaudara dalam perbedaan dan berbeda dalam persaudaraan."

Ketika pendidikan agama Islam masih diajarkan dengan semangat eklusifisme dan truth claim yang cenderung intoleran, jangan berharap Pendidikan Agama Islam dapat turut meredam gejolak sosial yang sedang melanda bangsa ini. Dari sudut sosiologis, truth claim sudah banyak melahirkan berbagai konflik sosial-politik yang membawa perang antar agama yang sampai saat ini masih menjadi problem dan kenyataan yang tidak bisa dihindari. ${ }^{8}$ Padahal semua agama mengajarkan perdamaian, dan umat manusia yang plural itu juga merupakan umat manusia yang satu karena berasal dari sejarah dan keturunan yang sama, yaitu Adam dan Hawa. Namun, kenyataan sebagai umat mayoritas yang memiliki tanggung jawab besar dalam membangun bangsa tersebut bukan berarti meniadakan tanggung jawab umat

\footnotetext{
${ }^{7}$ Abuddin Nata, Metodologi Studi Islam (Jakarta: Grafindo, 2000), 34.

${ }^{8}$ Budhi Munawar Rachman, Agama Masa Depan Perspektif Perenial (Jakarta: Paramadina, 1995), 25.
} 
lainnya, tentunya siapapun yang mengaku putra bangsa tanpa memandang ras, warna kulit maupun agama memiliki tanggung jawab dalam menjaga keutuhan bangsa ini, bahkan atheis sekalipun. Tapi sebagai kaum mayoritas, Islam tentunya mendapatkan porsi yang lebih dalam memikul tanggung jawab tersebut. Sebab, jika Indonesia gagal sebagai sebuah bangsa sama saja artinya bahwa Islam yang dianut lebih dari 90 persen penduduknya telah gagal memberikan solusi yang baik dalam kehidupan berbangsa dan bernegara.

Akan tetapi, kenyataan bahwa Islam merupakan agama terbesar di negara ini secara kuantitatif tidak lantas menghalalkan umat Islam untuk memonopoli kebenaran, dan peranan dalam membangun bangsa ini. Umat lain (nonMuslim) juga harus diberikan kesempatan dan peranan dalam memberikan kontribusinya dalam membangun bangsa. Karenanya konsep pluralisme dalam membangun Bangsa Indonesia akan sangat dibutuhkan, atau bahkan menjadi sebuah keharusan dan kewajiban. Bagaimana mungkin kita bisa berbicara membangun sebuah Indonesia jika dalam menyikapi kehidupan yang majemuk kita belum bisa untuk duduk saling berdampingan antara satu dan lainnya. Pengembangan pendidikan Islam haruslah mampu menciptakan ukhuwwah insāniyyah (persaudaraan sesama manusia) dalam arti yang luas, yang tidak hanya bersaudara sesama Muslim tapi juga bersaudara kepada manusia seluruhnya tanpa memandang perbedaan sebagai penghambat persaudaraan tersebut. Islam mengajarkan agar semua agama harus tetap dilindungi, dan para pemeluknya harus diberi kebebasan untuk melaksanakan agamanya. ${ }^{9}$

Islam yang humanis atau Islam yang pluralis, memandang kesatuan manusia sebagai mahluk ciptaan Allah, memiliki asal-usul yang sama, menghidupkan rasa perikemanusiaan, dan mencita-citakan pergaulan hidup yang lebih baik, seperti selalu berprasangka baik, disiplin, jujur, berbuat baik kepada sesama manusia, dan berlaku adil. Sedangkan Islam yang toleran mengandung arti bersikap menghargai pendapat, pandangan, kepercayaan, atau kebiasaan yang berbeda dengan pendirian seseorang, juga tidak memaksa, tetap berlaku baik, lemah lembut, dan saling memaafkan. Dari pemahaman humanisme, pluralisme, toleran, maka akan melahirkan sikap demokratis yang didapat dari kehidupan sehari-hari. Demokratis berarti mengutamakan persamaan hak dan kewajiban serta perlakuan yang sama bagi sesama dengan mengutamakan kebebasan berekspresi, berkumpul, dan mengemukakan pendapat sesuai dengan norma dan hukum yang berlaku. ${ }^{10}$

Karenanya, peranan lembaga-lembaga pendidikan (Islam) sangat penting dalam upaya internalisasi nilai-nilai tersebut. Ini pekerjaan yang tidak mudah, tetapi harus diupayakan terus-menerus. Jika keutuhan bangsa ini memang ingin kita jaga dan di pelihara. Oleh sebab itu pola pikir (mindset) harus diubah agar konsep pluralisme diterima sebagai sebuah kenyataan dalam berbangsa dan

\footnotetext{
${ }^{9}$ M. Amin Abdullah, Pendidikan Agama Era Multikultural Multireligius (Jakarta: PSAP, 2005), 57.

${ }^{10}$ Saihu dan Abdul Aziz, "Implementasi Metode Pendidikan Pluralisme dalam Mata Pelajaran Pendidikan Agama Islam,” Belajea: Jurnal Pendidikan Islam 5, no. 1 (2020): 131-150.
} 
bernegara. Sifat egoistik agama, suku, tradisi, dan latar belakang sejarah harus ditundukkan kepada kepentingan keutuhan bangsa dan negara. Untuk mewujudkan pengembangan pendidikan agama semacam itu, maka seseorang perlu memperkuat pengetahuan dan wawasan keislamannya, antara lain dengan jalan melihat Islam sebagai doktrin dan sekaligus peradaban. ${ }^{11}$ Keduanya bisa dibedakan, tapi tidak dipisahkan karena keduanya berasal dari sumber yang sama. Islam sebagai doktrin dan peradaban dalam istilah yurisprudensi Islam bisa dibedakan antara masalah ibadah dan mu'amalah. ${ }^{12}$ Untuk itu, peranan dan kualitas guru akan sangat menentukan kemana pendidikan akan diarahkan. Seluruh pusat dan jenjang pendidikan Islam dalam pandangan Syafi'i Ma'arif harus diarahkan kepada pembentukan pribadi $\bar{u} l \bar{u}$ al-albāb, $\bar{u} l \bar{u}$ al-nuhă, dan $\bar{u} l \bar{u}$ al-abșār, di samping sosok ummat al-'amal. ${ }^{13}$

Dalam hal ini, maka gurulah yang menjadi remote control dalam mengarahkan pusat dan jenjang pendidikan ke arah yang telah dijelaskan tersebut. Dengan diarahkannya pendidikan kepada $\bar{u} l \bar{u}$ al-albāb, $\bar{u} l \bar{u}$ al-nuḩa dan $\bar{u} \bar{u}$ al-abșār , serta ummat al- 'amal yang berarti punya pikiran, pengertian, kecerdasan, punya visi, penglihatan dan persepsi yang tajam, maka peserta didik yang telah sampai kepada titik itu diharapkan bisa menjadi seorang yang memiliki toleransi yang tinggi dan mengedepankan otak daripada otot dalam menyikapi perbedaan khususnya perbedaan beragama. Dengan penglihatannya yang tajam serta kecerdasannya memahami agama maka peserta didik akan dapat melihat bagaimana pentingnya nilai kemanusiaan, sehingga tidak ada alasan untuk menghancurkannya apalagi dengan topeng agama. Karena sejatinya agama manapun (khususnya Islam) cukup memandang mulia nilai kemanusiaan.

Karena perannya sebagai remote control dalam mengarahkan pendidikan kepada peserta didiknya, maka dalam hal internalisasi nilai pluralisme seorang guru khususnya guru Pendidikan Agama Islam harus bisa paham dengan benar dan baik apa yang semestinya ia lakukan. Oleh karena itu, ada beberapa alternatif model pembelajaran (Pendidikan Agama Islam) yang mestinya dilakukan oleh para guru mata pelajaran Pendidikan Agama Islam sekarang ini supaya bisa menghasilkan output pendidikan yang inklusif, berwawasan pluralis, dan apresiatif terhadap perbedaan. Pertama, membentuk pola pikir siswa secara terbuka untuk bersedia memberikan kesempatan kepada orang lain untuk meyakini kebenaran agama yang mereka anut, di luar keyakinannya. Oleh karena itu, kita harus menghindari penyampaian pesan-pesan Islam secara ideologis, doktrinal yang akan mengedepankan truth claim dalam beragama. Kita harus menyampaikan pula kepada peserta didik bahwa di luar paham kita ada paham lain yang tidak mustahil mengandung kebenaran dan diyakini oleh

\footnotetext{
${ }^{11}$ Nurcholis Madjid, Islam Doktrin dan Peradaban: Sebuah Telaah Kritis tentang Masalah Keimanan, Kemanusiaan dan Kemoderenan (Jakarta: Paramadina 1992), 234.

${ }^{12}$ Muhaimin, Rekonstruksi Pendidikan Islam, 319.

${ }^{13}$ Syafi'i Ma'arif, Masa Depan Bangsa dalam Taruhan, 229.
} 
pengikutnya. Dengan demikian, diharapkan siswa akan lebih mudah bergaul dan berinteraksi dengan orang lain, yang berbeda agama, ras dan etnis.

Kedua, membentuk pola pikir siswa untuk bisa menghargai perbedaan secara tulus, komunikatif, inklusif, dan tidak saling curiga, di samping meningkatkan iman dan taqwa. Oleh karena itu, kita harus menghindari penyampaian pemahaman Islam yang hanya bertumpu pada tekstual normatif. Sudah saatnya siswa harus mengkaji model-model pemahaman Islam, dan mengkontekstualisasikannya dalam kehidupan nyata agar dapat menghasilkan cara pandang yang utuh dan apresiatif terhadap perubahan dan perkembangan zaman yang pluralistik dan komprehensif, yakni dengan pendekatan filosofis dan historis. ${ }^{14}$ Ketiga, para pendidik dalam menyampaikan materi pendidikan harus secara jujur, transparan serta membuang subyektifitas sejarah dan kepentingan pribadi. Sehingga materi pendidikan Islam bisa dipahami oleh peserta didik dalam kehidupan praksis. Pendidik jangan memposisikan diri sebagai "agen/penyalur" mazhab tertentu dengan menyalahkan mazhab yang lain. Dalam hal ini, sangat diperlukan tenaga pendidik yang mampu menerjemahkan pesan-pesan universal keagamaan dengan baik, dan harus mampu menegakkan demokrasi yang mengakomodasi perbedaan.

Keempat, para pendidik haruslah memahami bahwa pendidikan bukanlah sekedar transfer informasi tentang ilmu pengetahuan dari guru kepada murid, melainkan suatu proses pembentukan karakter. Dalam hal ini ada tiga misi pendidikan yaitu transfer of knowledge (pewarisan pengetahuan), transfer of culture (pewarisan budaya), dan transfer of value (pewarisan nilai). ${ }^{15}$ Dengan demikian, dalam pendidikan Islam, kompetensi kognitif, afektif dan psikomotorik harus benar-benar menyatu dan termanifestasikan dalam kehidupan peserta didik. Oleh karena itu, peserta didik jangan hanya didoktrin tentang kesalehan vertikal/individual, tetapi juga kesalehan sosial. Kelima, Para pendidik perlu membiasakan anak-anak mengalami pertukaran budaya (cross cultural exchange) dengan sesama peserta didik. Pengalaman ini akan dapat membantu mereka untuk memahami orang lain dalam sebuah perbedaan. Dengan demikian, persatuan dan kesatuan pada akhirnya akan menjadi keinginan yang kuat di kalangan mereka. Kedamaian yang senantiasa kita nanti-nantikan akan menjadi kenyataan sesuai dengan peran agama yang membawa pesan perdamaian bagi umat manusia.

Dengan beberapa poin di atas penulis berharap dengan keyakinan bahwa pendidikan (Islam) akan mampu membawa angin segar dalam peradaban yang lebih baik serta mampu menampilkan wajah Islam yang inklusif, pluralis dan apresiatif terhadap perbedaan.

\footnotetext{
${ }^{14}$ Komarudin Hidayat, Menafsirkan Kehendak Tuhan (Jakarta: Teraju, 2004), 34.

${ }^{15}$ Buchari Alma, dkk, Moral dan Kognisi Islam (Bandung: Alfabeta, 2009), 2.
} 


\section{Peran Pemimpin Agama Bagi Terciptanya Kesadaran Pluralisme}

Pluralisme agama yang merupakan tolok ukur atas kemajuan suatu bangsa, harus bisa benar-benar dijaga dan disadari urgensitasnya bagi seluruh masyarakat Indonesia tanpa terkecuali. Ini pekerjaan yang tidak mudah, tetapi harus diupayakan secara terus-menerus, jika keutuhan bangsa ini memang ingin kita jaga dan pelihara. Oleh sebab itu pola pikir (mindset) harus diubah agar konsep pluralisme diterima sebagai sebuah kenyataan dalam kita berbangsa dan bernegara. Sifat egoistis agama, suku, tradisi, dan latar belakang sejarah harus ditundukkan kepada kepentingan keutuhan bangsa dan negara. Karenanya, di samping peran pendidikan (Islam), pemimpin agama juga mempunyai peranan yang tak kalah penting dalam hal mengembangkan sayap dan sikap pluralisme dalam kehidupan majemuk demi keutuhan bangsa ini. Islam dengan segala macam ekspresi yang dimilikinya dalam konteks keindonesiaan memiliki potensi besar untuk bisa dengan mudah mengembangkan budaya dan sikap pluralisme. Kuncinya pemimpin-pemimpin dari segala macam ekspresi Islam tersebut harus mampu dan bisa menggiring umatnya menuju Islam yang rahmah li-al-'ālaminn.

Seperti bagian awal literatur politik yang diwarisi dari zaman Nabi Muhammad SAW adalah Șahîfat al-Madīnah, yakni dokumen yang dikenal sebagai piagam madinah yang kebanyakan dihubungkan dengan episode Hijrah antara tahun 662-624 M. Konstitusi ini menyebut kaum mukmin membentuk satu ummat yang menyertakan kaum Yahudi Madinah. Meskipun terdiri atas suku-suku, tapi masing-masing harus bertanggung jawab atas prilaku anggotanya. Umat sebagai satu keseluruhan bertindak secara kolektif dalam menegakkan tatanan sosial dan keamanan, serta dalam melawan musuh saat perang dan damai. Secara garis besar, Piagam Madinah adalah piagam pertama dalam sejarah peradaban Islam yang menyepakati soal-soal hubungan atau interaksi sosial antara kelompok-kelompok yang memiliki perbedaan agama dan budaya, yakni antara kelompok Yahudi, Nasrani dan Muslim. Di sini, Nabi Muhammad SAW bertindak sebagai pencetus dan mediator dalam gerakan ișlāh (damai), hal hal penting yang dapat dijadikan sebagai dasar interaksi sosial di tengah komunitas yang plural. ${ }^{16}$

Perlu kiranya di sini dikutip beberapa bagian teks piagam madinah tersebut seperti yang dinukil oleh sejarawan Islam klasik seperti Ibn Hishām dalam kitabnya al-Sayrah al-nabawiyyah, sampai sejarawan masa kini seperti A Basith Badar, dalam al-Tārīkh al-shāmil li-al-madīnah al-munawwarah, sebagai berikut:

"Sesungguhnya orang-orang Yahudi berkewajiban menyediakan biaya bersama orang-orang mukmin selama mereka berperang bersama dan

\footnotetext{
${ }^{16}$ Muhammad Abdul Halim Sidiq dan Rohman, "Pluralisme Perspektif Pendidikan Islam: Relevansi Gagasan Abdurrahman Wahid dalam Konteks Keindonesiaan,” Tarbiyatuna: Jurnal Pendidikan Islam 2, no. 1 (Februari 2015): 46-95.
} 
sesungguhnya bagi orang Yahudi Bani Auf menjadi satu umat dengan orang-orang Islam. Orang-orang Yahudi menjalankan agamanya masingmasing, termasuk keluarga dan dirinya sendiri, kecuali orang yang berbuat zalim dan kejahatan, resikonya akan ditanggung sendiri. Bagi orang-orang Yahudi Bani Najjar, Bani Haris, Bani Sa'adah, Bani Jusam, Bani 'Aus Bani Tsalabah dan Ja'fah, juga Bani Syutaibah, berlaku ketetapan sebagaimana Yahudi Bani 'Auf di muka. Bagi komunitas Yahudi dikenakan biaya untuk mereka sebagaimana dikenakan terhadap orangorang Islam, dan mereka memperoleh jaminan pertolongan menghadapi orang/pihak yang memerangi para pendukung piagam ini. Mereka memperoleh pemebelaan terhadap siapa pun yang mengancam keamanan Yatsrib (Madinah). Mereka aman untuk keluar masuk (menetap atau bepergian dari Madinah) selama tidak berbuat kezaliman atau kejahatan." 17

A Basith Badar memberi komentar bahwa piagam ini jelas merupakan kontrak politik yang menarik, sebagai berikut. Pertama, pernyataan kesatuan umat Islam atas dasar ikatan-ikatan yang baru, yakni ikatan keimanan, bukan lagi ikatan kabilah atau ras. Kedua, membangun solidaritas umat dalam menghadapi kesulitan-kesulitan sosial dan ekonomi. Ketiga, memberikan jaminan keamanan dan pertolongan atau perlindungan kepada komunitas Yahudi di Madinah, baik dalam menjalankan agamanya, atau keamanan keluarga dan hartanya, dan juga berkewajiban bersama-sama orang Islam untuk membela dan mempertahankan Madinah. Keempat, memberikan perlindungan keamanan kepada semua penduduk Madinah keseluruhannya, selama tidak melakukan kezaliman dan kejahatan, dan seterusnya. Sebagai salah satu produk sejarah umat Islam, Piagam Madinah merupakan bukti bahwa Nabi Muhammad SAW berhasil menerapkan nilai-nilai keadilan, prinsip-prinsip kesetaraan, toleransi, penegakan hukum yang adil, jaminan kesejahteraan bagi semua warga, serta perlindungan terhadap kelompok minoritas. ${ }^{18}$

Namun jika di kemudian hari terjadi konflik antara komunitas muslim Madinah dengan komunitas Yahudi, seperti peristiwa Bani Qaynuqā’, Khaybar, dan lain-lain, juga pengusiran orang-orang Yahudi dari wilayah Madinah atau sekitarnya, adalah karena terjadinya penghianatan dan konspirasi yang dilakukan orang-orang Yahudi dengan musuh-musuh Islam, khususnya orangorang Quraish Mekkah. Dan selama itu tidak pernah terjadi bentrok antara Yahudi dengan Islam dalam masalah agama atau keyakinan, sebab umat Islam sendiri sudah mempunyai sikap dan pemikiran yang inklusif menghadapi mereka yang non-Islam dengan pijakan Alquran, "lakum dīnukum waliya dīn" (bagimu agamamu bagiku agamaku), karena Alquran mengajarkan orang-orang

\footnotetext{
${ }^{17}$ Muhammad Tolhah Hasan, Ahlusunnah Wal Jama'ah dalam Persepsi dan Tradisi NU (Jakarta: Lantaboras Press, 2005), 340-341.

${ }^{18}$ Darwis Sadir, "Piagam Madinah (Al-Qanun)," Jurnal Pemikiran dan Pembaharuan Hukum Islam 5, no. 1 (2013): 250-57.
} 
Islam agar hidup berdampingan secara damai (peaceful co-existence) dengan siapapun, tanpa harus melakukan pemaksaan dalam masalah agama (lā ikrāh $f i$ al-dīn) apa lagi kekerasan. ${ }^{19}$

Dari kutipan piagam Madinah dan komentar A Basith Badar tersebut nampak jelas bahwa bangsa atau negara yang didirikan oleh Nabi Muhammad memberikan jaminan keamanan kepada seluruh penduduknya, meskipun berbeda agama, suku dan ras, selama mereka tidak berbuat zalim dan kejahatan, karena keberagaman adalah sebuah keniscayaan yang harus dijaga demi membentuk suatu bangsa yang maju lagi makmur. Inilah ajaran pluralisme agama Islam Nabi Muhammad SAW yang mengutamakan persatuan dan perdamaian di atas semua perbedaan, karena perbedaan tidak harus selalu disikapi dengan kekerasan selama tidak ada kejahatan dan kezaliman terhadap umat Islam. Dalam konteks ke-Indonesiaan, kita bisa lihat contoh besar dari ekspresi ke-Islaman tersebut seperti Muhammadiyah dan Nahdlatul Ulama. Keduanya sudah cukup besar dan mumpuni dalam mengurusi umat (Islam) di Indonesia. Ketika keduanya bisa menggiring umatnya ke arah Islam yang inklusif sehingga prinsip pluralisme tidak akan dijadikan masalah, maka Islam Indonesia dalam waktu dekat akan bisa benar-benar berfungsi sebagai rahmat bagi alam khususnya bagi Indonesia.

Karenanya, penulis berharap, kita selaku umat Islam memang seharusnya berpikir inklusif, mengedepankan perdamaian di atas perbedaan sebagaimana dicontohkan Nabi Muhammad SAW ketika memimpin Madinah. Sebab, negara kita terbentuk karena bersatunya seluruh umat beragama untuk melawan penjajah. Kita tidak bisa menghilangkan kontribusi orang-orang yang berbeda agama, suku, ras dan sebagainya terhadap negara kita. Karena semuanya sudah tertulis jelas dalam buku sejarah. Oleh sebab itu rumusan Bhineka Tunggal Ika yang telah dicetuskan oleh founding father's kita memang sangat relevan untuk dijadikan prinsip berbangsa dan bernegara, selain itu memang ajaran Islam juga melihat kemajemukan masyarakat yang ada di indonesia kita tercinta agar bisa hidup rukun dan damai.

\section{Kesimpulan}

Dari uraian tentang pluralisme agama dan urgensi implementasinya dalam pendidikan Islam yang sudah dijelaskan, dapat diambil kesimpulan sebagai berikut. Pluralisme sangatlah dihargai oleh Alquran sebagai hukum Islam. Masyarakat terdiri dari berbagai macam komunitas yang beragam dan berbeda. Dengan keragaman dan perbedaan tersebut kita selaku umat Islam harus membuka pemikiran yang inklusif dan membuka lebar-lebar wacana berpikir untuk memahami perbedaan dan substansi ajaran Islam secara benar, tidak mengedepankan sikap fanatisme buta namun mengedepankan sikap toleransi dan perdamaian, agar agama Islam memang mampu menjadi rahmah li-al'ālamīn, karena Alquran bersifat sangat demokratis terhadap pluralisme agama

\footnotetext{
${ }^{19}$ Ibid., 342.
} 
dan memandangnya sebagai sebuah fenomena dan tidak menghendaki adanya perseteruan antar agama (clash) karena sejatinya seluruh ajaran agama Islam adalah bermuara kepada perdamaian, bukan pemaksaan, kekerasan, bukan pula pembunuhan.

Untuk mengembalikan konsep tentang pluralisme agama, perlu kiranya merujuk kepada sang revolusioner dunia Nabi Muhammad SAW, yang mampu menjaga keutuhan kota madinah diatas perbedaan dan kemajemukan umat pada masa itu. Tentunya ini tidak lain, karena beliau faham konsep tentang pluralisme agama tersebut dengan bertendensi kepada Alquran sebagai sumber utamanya. Dalam hal ini pendidikan Islam berperan sebagai penyalur pengetahuan, budaya dan nilai-nilai ajaran Islam yang telah dicontohkan oleh Nabi Muhammad SAW, demi menjaga keutuhan bangsa dan menebarkan perdamaian pada seluruh umat manusia bahwasanya agama Islam adalah agama yang rahmah li-al-' 'älamīn.[]

\section{Daftar Rujukan}

Abdullah, M. Amin. Pendidikan Agama Era Multikultural Multireligius. Jakarta: PSAP, 2005.

Alma, Buchari, dkk. Moral dan Kognisi Islam. Bandung: Alfabeta, 2009.

Aziz, Saihu dan Abdul. "Implementasi Metode Pendidikan Pluralisme dalam Mata Pelajaran Pendidikan Agama Islam." Belajea: Jurnal Pendidikan Islam 5, no. 1 (2020): 131-150.

Hasan, Muhammad Tolhah. Ahlusunnah Wal Jama'ah dalam Persepsi dan Tradisi NU. Jakarta: Lantaboras Press, 2005.

Hidayat, Komarudin. Menafsirkan Kehendak Tuhan. Jakarta: Teraju, 2004.

Ma'arif, Ahmad Syafi'i. Islam dalam Bingkai. Yogyakarta: Pustaka SM 2009.

Ma'arif, Ahmad Syafii. Masa Depan Bangsa dalam Taruhan. Yogyakarta: Pustaka SM, 2000.

Madjid, Nurcholis. Islam Doktrin dan Peradaban: Sebuah Telaah Kritis tentang Masalah Keimanan, Kemanusiaan dan Kemoderenan. Jakarta: Paramadina 1992.

Mahmudin, Afif Syaiful. "Pendidikan Islam dan Kesadaran Pluralisme." Ta'limuna: Jurnal Pendidikan Islam 7, no. 1 (Maret 2018).

Muhaimin, Muhaimin. Rekonstruksi Pendidikan Islam. Jakarta: Pustaka setia, 2009.

Nata, Abuddin. Metodologi Studi Islam. Jakarta: Grafindo, 2000.

Rachman, Budhi Munawar. Agama Masa Depan Perspektif Perenial. Jakarta: Paramadina, 1995.

Sadir, Darwis. "Piagam Madinah (Al-Qanun)." Jurnal Pemikiran dan Pembaharuan Hukum Islam 5, no. 1 (2013): 250-57.

Shihab, M. Quraish. Membumikan Al-Qur'an. Bandung: Mizan, 1995.

Sidiq, Muhammad Abdul Halim, dan Rohman Rohman. "Pluralisme Perspektif Pendidikan Islam: Relevansi Gagasan Abdurrahman Wahid dalam 
Konteks Keindonesiaan." Tarbiyatuna: Jurnal Pendidikan Islam 2, no. 1 (Februari 2015): 46-95.

Uhbiyati, Nur. Pendidikan Islam. Jakarta: Pustaka Setia, 2000. 